\title{
Tropical Imaginings and Romantic Nostalgia: 75 Years of Giliw Ko and the Colonial Gaze
}

\author{
Amy Forbes
}

\author{
James Cook University
}

\begin{abstract}
In 1998, Australia restored the 1939 film musical, Giliw Ko, the earliest extant film ever produced in the Philippines. Through its National Film and Sound Archive, Australia presented the film as a gift to the Filipino people to mark 100 years of independence. Celebrating its $75^{\text {th }}$ year of production next year, the film as gift is ironical as it can be argued that the Philippines never gained independence, at least not from the strong colonizing effects of over 50 years of US rule. Giliw Ko tackles themes of a people's infatuation and confusion over Hollywood images and what it means to be cultured and Westernized. In this essay, I explore American cinema's historical and cultural constructs as a natural continuation of the colonialist project that is based on binary oppositions of West/East, civilized and uncivilized, conqueror and conquered. Utilising the film Giliw ko, I examine these constructs that are carried to the present day in Philippine cinema.
\end{abstract}

\section{A Colonialist Beginning}

$\mathrm{T}$ he United States was a late entrant in the colonial game. In his book, In Our Own Image: America's Empire in the Philippines, Stanley Karnow (1989) presents an account of how this former colony became a colonialist herself (p. 79) The Spanish-American war of 1898 was an attempt by the United States to liberate Cuba from Spanish oppression. The Philippines itself, had been under Spanish rule for the last 300 years. American Commodore George Dewey and his squadron of nine ships entered Manila Bay on April 30, 1898 and waited a few hours before launching an attack that destroyed the entire Spanish Armada. It was a heady experience for the Americans who soon practiced the same exaggerated selfconsciousness that afflicted the Europeans earlier. Kipling wrote his famous poem "The White Man's Burden" to exhort Americans to "bestow the blessings of their civilization on the Philippines - though, he warned, it would be a thankless task" (1989, p. 11).

And just as the Spanish before them, the next set of conquistadores, the Americans found a malleable culture especially useful in light of the educating mission they came with. Their contributions included among others, public health and a system of roads. The 50 years under American rule enabled the United States to establish in the Philippines political, economic and socio-cultural structures couched in the rubric of liberal democracy. The teaching of the English language further facilitated the infusion of American culture onto the Philippines' own. English served as the lingua franca to cement the links between the more than 7,000 islands making up the country.

\section{Cinema and the Western Gaze}

Even before the invention of cinema, Europeans and Americans delighted in the invention of photography or still pictures, as it was then called. More than anything, photography enabled ordinary people to obtain likenesses of themselves without having to pay large sums of money to painters and portrait artists as was the custom in earlier years. Also, photography enabled individuals to keep likenesses of departed loved ones. And so when cinema was 
introduced at the turn of the century, it created quite a stir as not only did it preserve likenesses, it presented a vision of people as they talked, laughed and moved about.

While there had been numerous attempts and inventions to capture motion prior to the unveiling of the Cinematographe in1895, Louis Lumiere's camera is considered by film historians as the official beginning of cinema as we know it today (Mast \& Kawin, 2006). Lumiere's first film was entitled La Sortie des Usines or Worker Leaving the Lumiere Factory. He followed this with several shorts, among them, L'Arrivee d'un Train en Gare or Arrival of a Train which, it is said, when shown at the local theatre, appeared too real that cinema patrons screamed and jumped from their seats in fear (2006, p.33).

Lumiere's work is contrasted with American inventor Thomas Edison's work. Unlike Lumiere's portable camera, Edison's camera and studio called the Black Maria, remained where it sat and people and other items of the world were brought to it to perform (2006, p.30). Among Edison's early films were Serpentine Dance performed by Annabelle, The Miller's Mishap, and Pile Driving, Washington Navy Yard (Barnouw, 1993). Some of these films were real documentaries of everyday life, while a number were reconstitutions. Reconstitution meant combining footage of actual events with faked studio shots to complete the story. For example, Edison combined actualities of the 1906 San Francisco earthquake with shots of miniatures of the devastated city. Biograph's Eruption of Mount Vesuvius was also such a film. In any case, these films were considered as documentaries, actualities, topicals, or after 1907, as travelogues. And throughout the world, many new theatrical enterprises were set up with great success.

The leading film producers at the turn of the century were nations with colonial empires. In America, Hollywood became the symbol of American dominance in the economic, political and cultural realms (Richardson, 2010). The Spanish-American War was a godsend to the young film industry that by this time was quickly losing its lustre. Re-enactments and actualities of American troops in battle and colonialist expansion and military intervention rekindled interest among the cinema-going public (Chapman, 2009).

In the Philippines, it is generally accepted that a Spaniard, Antonio Ramos, was responsible for bringing the technology to the country in 1899 (de Pedro, 1995). The films produced reflected the colonialists' attitudes toward their colonies as well as themselves as colonisers. Film historian Erik Barnouw (1993) notes that most early films of "natives" portrayed them as charming, quaint, sometimes mysterious, generally loyal and grateful for the protection and guidance of their colonial masters. These films reassured colonisers that they were doing the right thing and bringing progress to the backward people of the world. What is striking is that while these films "show" the "native", they are also portraits of the creator; of the colonisers as they saw or believed themselves to be. They are a record of how Western identities were constructed through the active silencing of the relations of ethnicity, gender and class. As such, they are useful in present-day projects of interrogating prevailing colonialist systems of knowledge.

In the project of uncovering sites of oppression and silencing, it is useful to discuss Edward Said's notion of "orientalism" which he discusses in his book of the same title. According to Said, "Orientalism" is a "mode of discourse by which European culture (British and French) was able to manage - and even produce - the orient politically, sociologically, militarily, ideologically, scientifically and imaginatively during the post-Enlightenment period" (Said, 
1978). It is a construct of the "Orient" with supporting institutions, vocabulary, imagery, etc. (Legasto, 1993). For instance, some Western universities have departments of Oriental Studies, subjects in Oriental History and the like. In the vocabulary, women's names have been appropriated for use to name conquered territories such as Virginia, Carolina, etc. Colonial postcards, novels and even present- day cinema perpetuate the myth of the "dark continent" and of virginal lands waiting to be ravaged, subdued and conquered. There are also the doctrines such as "the white man's burden," "evangelical mission," "path to enlightenment" and U.S. President McKinley's "Benevolent Assimilation Proclamation" of 1898 as justification for colonialist projects in the Philippines. (1993).

These are examples of ways by which countries such as the Philippines have been made into the "other," or to what Indian critic Gayatri Chakravorty Spivak refers to as the practice of "world-ing." (Spivak, 1985) Using archival material, she studied how representations of "historical reality" were fabricated by the British Empire through the East India Company, which then became the "reality" of the Northern Hill States. (1985).

Another example is Reynaldo Ileto's essay "U.S. Conquest and the Production of Knowledge about the Philippines: A Preliminary Inquiry (1991). In this essay, Ileto focuses on the Pulitzer prize-winning book, In Our Image: America's Empire in the Philippines, by American journalist Stanley Karnow. He challenges Karnow's claim that the reason America failed in its experiment in democracy was because the Philippines held closely to its traditional values. Ileto sees Karnow's assertion as part of the American-produced knowledge that explains the Philippines' continuing present-day ills as being the product of something within the local culture rather than as the result of disruptive and destructive colonisation.

Stanley Karnow's book, In Our Image, was adapted for American television in 1989 with Karnow himself writing and narrating the work. It was produced for Public Broadcasting and has since been aired on various Public Broadcasting Service member stations in the United States. That the book was turned into a film raises questions concerning film's (in this case, the documentary genre's) complicity with Eurocentrism and ideological claims to realism and objectivity. The frozen title shot speaks eloquently of this. The documentary's title has been superimposed on a short American-produced film passed off as genuine but which in later years was discovered to be a re-enactment of the Philippine-American war. Thomas Edison shot this film in his West Orange, New Jersey back lot.

The few remaining prints of early American-made films about the Philippines have in recent years, been found to be re-enactments or outright fakeries. Some ask: what do these films contribute to our understanding of history? Are they innocent representations? (del Mundo, 1993)? Pascal Bonitzer, in his essay "It's Only a Film/ou La face du Neant" says these films are innocent because they are characterized by the absence of the "look".

There was first of all the twenty-odd years during which the cinema was content merely to be the object of viewing, recording phenomena and movements and the sights of the world. When today we see those early films ... we are seeing the varied fruits of a kind of cinematic Eden where the coldness and sophistication of the look had not yet penetrated. The impression is usually spoken of in terms of freshness and innocence. A cinema where the only currency was that of gesture, where the viewer's eyes are functioning but not looking. (Bonitzer as cited in Del Mundo, 1993). 
This is all well and good. However, historical evidence shows us that early films did have a "look" and that these were invariably those of the colonizer's. While most early films showing happy "natives" assured western audiences about their colonial system, there were disturbing exceptions. The 1903 film Native Woman Coaling a Ship and Scrambling for Money made in the West Indies by an Edison cameraman "presented a picture of degradation such as seldom reached the screen"(Barnouw, 1993).

\section{Philippine Examples}

The Philippines was among the first countries in the world to be exposed to the new medium of cinema. As a colony of Spain at the time, it was no accident that it was a Spaniard who introduced cinema to the country. A Señor Pertierra (whose first name does not appear on any records) managed to import a Gaumont Cinematographe (similar to Lumiere's Cinematographe) from Barcelona in late 1896 (de Pedro, 1995). It was not until January 1 of 1897 that Señor Pertierra was finally able to exhibit his films at No. 12 Escolta. Billed as Espectaculo Cientifico de Pertierra, the presentation consisted of four short films (about one minute each): Man with a Hat, Japanese Dance, Boxing Bout, and The Plaza of the Paris Opera House (de Pedro, 1995).

Following Pertierra's lead, two Swiss gentlemen named Liebman and Peritz brought the Cinematographe to the Philippines in August 1897. They established a movie house also at Escolta near the corner of San Jacinto and began exhibiting films on August 28 (de Pedro, 1995). For their initial offering, they showed 10 short films which included Cortejo Arabe, Comparsa de Negros, El Fotograjo Ambulante, Pedrea en la nieve and 6 others (1995).

During the same period, film crews of Lumiere, Edison, the American Mutoscope and Biograph Company (AM\&B), and Burton Holmes' Travelogue fanned out across the world and some wound up in the Philippines. Unfortunately, most of these films had deteriorated (early films were made with nitrate which over the years tended to combust in storage) or had been burned during the Second World War. What do survive are paper prints of some 19 films at the U.S. Library of Congress Paper Print Collection. Before 1912, American copyright law did not cover motion pictures. Early film producers submitted paper contact prints of their films to the U.S. Copyright Office at the Library of Congress. These were made using light-sensitive material with the same width and length as the original negatives and developed as though a still photograph. Some motion picture companies such as Edison and the American Mutoscope and Biograph (AM\&B) submitted paper prints of the whole film while some companies merely submitted illustrative sequences (Library of Congress, 1995).

Many of these films contain evidence of the colonialist project. Common themes and tropes revolved around the conquering hero and masterful man, a romantic nostalgia for pure cultures, and topographical reductionism where the incursion of the West is constructed around the notion of bringing fertility and fecundity to the dry, barren land. Thissame structuring discourse in the so-called documentary films or re-enactments are evident in later feature and non-documentary films.

\section{Giliw Ko: An Example}

In 1998, the Australian government gifted the Filipino people with a restored copy of the earliest extant film in the Philippine. 


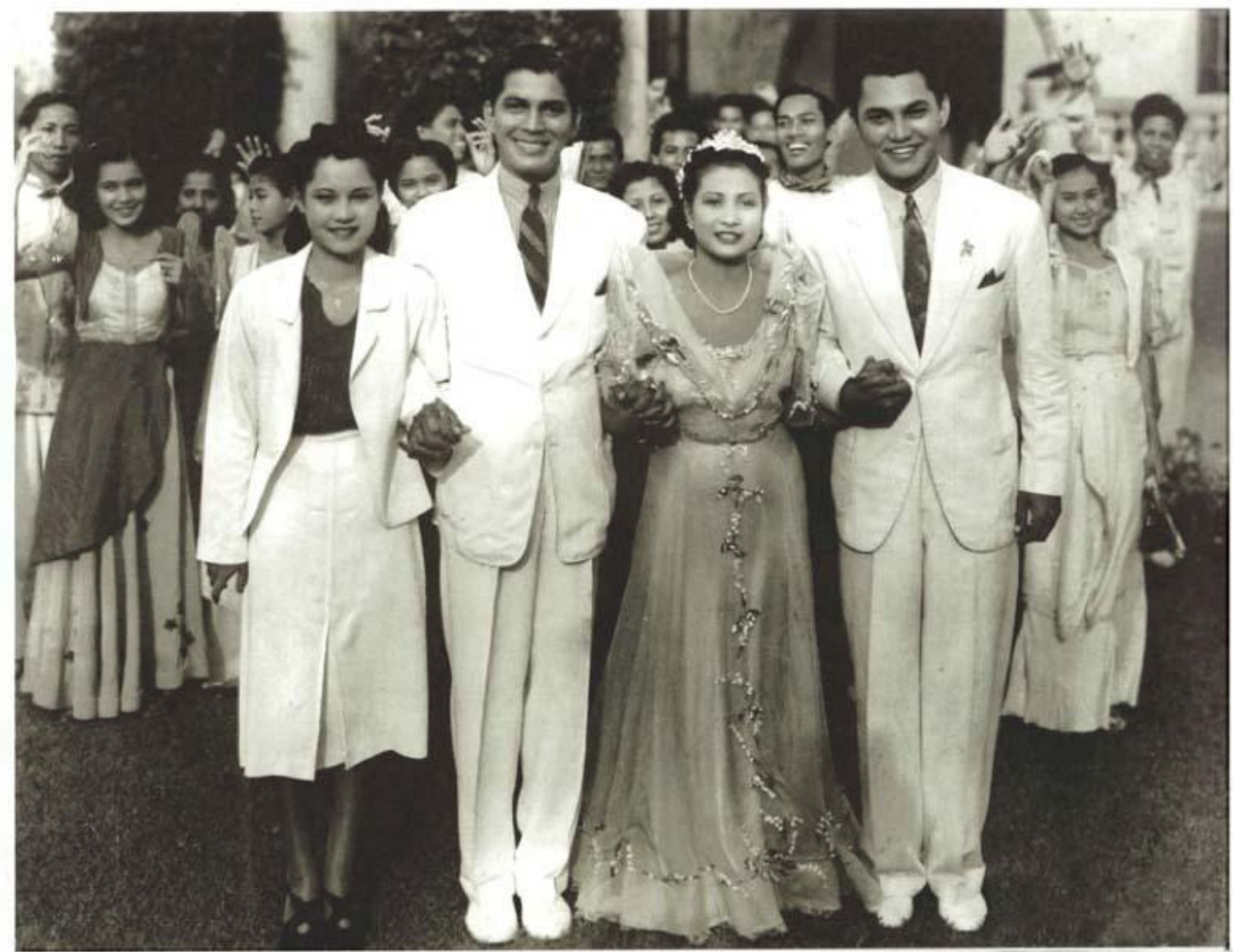

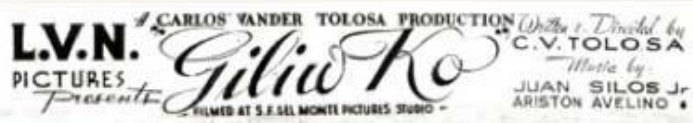

Giliw Ko (My Love) was produced in 1938 and released in 1939 by the newly formed LVN Pictures, Inc. It was premiered at the Metropolitan Theater with no less than the country's president in attendance.

In the film, Guia (Mila del Sol) is a young woman who has been adopted by Don Alvaro and Dona Luisa who are the owners of a large plantation or hacienda As is the practice in haciendas, the tenant or farm hand is expected not only to till the land, but to perform other tasks for the household. Guia is described by Don Alvaro as "the most fragrant flower of the hacienda." Her youth and beauty is so pure that all the young men were crazy about her. Two of the three male characters are vying for her attention. Jose (Fernando Poe, Sr.) is the young farmer whose life's task is to care for his blind father. The other male is Takio (Ben Rubio) who, as foreman of the hacienda, is portrayed as an even stricter taskmaster than the owner himself.

In the meantime, Guia's attention is not on men and suitors but on learning the latest American trends as she reads her American magazine. It is from magazines that she Iearns to say "Yoo-hoo" and "Hello" as well as to pout and purse her lips which she has learned to paint with lipstick. In reality, she is really a young child who sticks her tongue out at Takio whenever he tries to gain points with the master. While attracted to Jose, she insists that for her to pay him more attention, he should buy a suit, new shoes, a tie and a new hat in order to 
look more like the models in her magazine. This obsession with clothing and outward appearance is a motif throughout the film. All characters from the city are portrayed as wearing Western clothes while workers at the hacienda, including Guia and Jose, are in their native clothes. It is only when Guia is brought to the city that she dons a Western dress. Yet Takio, the foreman, wears riding boots and jodhpurs reminiscent of British colonial musters in India or Africa surveying their new territories.

Meanwhile, Antonio Lopez, who is the son of Don Alvaro, returns to the province from Manila. He is a musician and bandleader as well as a radio personality. He learns of his mother's ailment and decides to take her to Manila for treatment. He has heard of Guia's lovely singing voice and insists on listening to her during an impromptu serenade put together by all the plantation workers and tenants to honour his visit. He intends to take her to the city and in effect, westernise her, reminiscent of the male-oriented and civilising mission of the coloniser.

The duality, that is native and pure versus wordly and Westernised, that surrounds Guia's character is made evident when she meets the city-based, Antonio. Although Antonio made it quite clear that his interest in her is as a radio singing talent who he can bring to Manila, Guia fancies him as a suitor. With him, she loses her childlike ways and exhibits all the stereotypical wiles of a woman. When she learns of his impending marriage to a wealthy girlfriend Rosie (Fleur de Lis), she not only disobeys his order for her to sing a particular song, she also feigns a headache in order to leave the party early.

The same duality is echoed in the entire film. The usual dichotomies of rich/poor, Western/ non-Western, male/female are evident in the film. For instance, the film begins with a shot of Antonio conducting his orchestra. He is singing a popular tune in English. When he finishes to great applause, he announces: "And now ladies and gentlemen, our next offering is our very own native melody dedicated to each and every province in the Philippine Islands." He begins the familiar words of the folk song "Bahay Kubo" (Little Nipa Hut) and turns to conduct, not his Western band but a smaller group of musicians playing various "native" instruments such as the banduria and the bamboo organ, in effect clearly showing the difference between western and native music. The film director Carlos Vander Tolosa takes this opportunity to dissolve the scene from the city to idyllic shots of coconut trees and other "native" vegetation. The shot settles on a group of happy, singing natives - the rich father's tenant farmers.

Reminiscent of films showing happy, black farmers tending to cotton plantations in the American South, these poor farmers as shown smiling, their joyful and harmonious singing taking the hardship and boredom out of work. The lyrics of the song speak of the contented lives they lead. The land is portrayed as rich and abundant, reminiscent of some Garden of Eden awaiting the master's touch. The scene combines music with the metaphoric portrayal of the lands as virginal, coyly awaiting the master's touch.

Guia, herself, is shown as an object of desire as she is photographed from a high angle, thus exposing her face and neck to the camera. The male, Jose, is in the superior position as he is shown single-handedly lifting an abundant harvest of coconuts. His virility is established even as he replies to Guia in song.

Landlord-tenant relations have long been points of major conflicts in Philippine society. The rise of the Huk movement in the 1940s has been traced to the inequitable relationship 
between landlord and tenant. In this film, the use of the song offers a utopian world characterized by abundance, energy, transparency and community. Harmony is "managed" and the "imagined community" (following Benedict Anderson) elides the commonplace dreariness, fatigue and lack found in actual communities.

The story continues as Guia realises she can never be part of Antonio's world. When she tells Don Alvaro of her feelings for his son, he responds, "Don't be impertinent, girl." She is but a poor serving girl whose place is beside the equally poor farmer, Jose. Jose has been working on building a "bamboo radio" in order to hear Guia sing over the radio. It is a farfetched notion but it is the director's way of showing that Westernisation cannot be achieved by simply putting together indigenous materials. Jose's radio fails to work and he is forced to go to the master's house in order to participate in the very Western practice of listening to the radio. He asks the maid for the time as he does not own a watch. This contrasts a farmer's concept of time with the very regular rhythm of the technological world.

Following Guia's realisation that she can never compete for Antonio's affection, she, in the meantime, expresses her love for someone (Jose) who is closer to her station in life. She hurries back to the hacienda and is pursued by Antonio. He follows her not to profess love but rather, to insist that she return to the city to honour the singing contracts he has signed on her behalf. He reminds her that contracts are binding and that as an orphan and ward of his parents, he has control over her actions decisions. In fact, in the beginning of the film, Antonio's father Don Alvaro, expresses his desire for Guia to marry Takio, the foreman. Guia, herself, tells Jose that if he wished to marry her, he would have to ask permission from Don Alvaro.

The male characters are portrayed differently. In Antonio's case, as the wealthy character, he is shown riding a horse as he surveys his parent's coconut plantation. Jose is shown riding his lowly carabao. When Takio is sacked from his job as foreman, and José appointed in his place, Jose expresses great discomfort in wearing Tako's boots and stiff uniform.

The film's ending follows the typical Hollywood cliché. Marriage three-ways - Antonio to Rosie, Guia to Jose, and yes, even Takio the foreman to the housemaid, Atang - normalises relations. The fascination for the unattainable is echoed in the film's theme song that Antonio sings at the beginning of the film, and which Guia, on instructions to sing in English, proceeds to perform on radio:

I may sound silly and funny

Telling you these things.

But what I feel is funny.

My heart sings.

I'm so in love with you.

Darling what can I do?

Am I to blame

When I exclaim:

Love me, too.

The United States and the Philippines are linked by a history of colonial rule characterised by a warped mirroring of one another. The U.S. was (and continues to be) the "big brother" 
watching over the Filipinos who U.S. President William Howard Taft referred to condescendingly as "our little brown brothers" (Karnow, 1989).

Most of the people I initially met [in the Philippines] spoke Americanized English.... They knew far more about the United States than I knew about the Philippines as if they were some kind of lost American tribe that had somehow detached from the U.S. mainland and floated across the Pacific. (p. xi)

The United States, for all its "transparency", is protected by a glass curtain, invisible and unyielding. And much we get are warped images of ourselves. The critical study of turn-ofthe-century short/documentary/non-documentary films such as Giliw Ko (My Love) or Karnow's "objective" yet gossipy book In Our Image take on greater importance as we imagine and discover Western articulations of power within our own diverse cultures. It is through projects such as this that alternative historical narratives may be produced.

\section{Works Cited}

Barnouw, E. (1993). Documentary: A History of the Non-Fiction Film. London: Oxford University Press.

Chapman, J. (2009) Projecting Empire: Imperialism and Popular Culture. Retrieved from http://site.ebrary.com/lib/jcu/docDetail.action?docID=10359149\&page=13

Del Mundo, C. Jr. (1994). Native Resistance: Philippine Cinema and Colonialism. Unpublished Dissertation. University of Iowa.

De Pedro, E. 1995). "Conference on Cinema and Society: Reflections on the Development of Cinema in the Philippines. De La Salle University. February 22, 1995.

"Giliw Ko." (1939). 35mm film from LVN Studios (video transfer), approx. 1:30 in length.

Ileto, R. C. "U.S. Conquest and the Production of Knowledge about the Philippines, 18991902: A Preliminary Inquiry” (1991). Paper presented to the IAHA 12th Conference, University of Hongkong, 24-28 June.

---. “Clientelist Discourse in Philippine Studies -- A Critique". Paper delivered at the University of the Philippines, College of Social Sciences and Philosophy. February 23, 1995.

---. “Critical Questions on Nationalism: A Historian's View”. Professorial Chair paper presented at De La Salle University, August 12, 1985. Kaplan, E. Ann, ed. 1990. Psychoanalysis and Cinema. New York: Routledge.

Karnow, S. (1989). In Our Image: America's Empire in the Philippines. New York: Random House, Inc.

---. (1990). In Our Image: America's Empire in the Philippines video. produced by Los Angeles KCET station. 
Legasto, P. \& Hidalgo, C. eds. (1993). Philippine Post-Colonial Studies: Essays and Language and Literature. Diliman, Quezon City: University of the Philippines Press.

Library of Congress Paper Print Film Collection. (1995). Collection of 21 films on the subject of Philippines produced by the Edison Company and the American Mutoscope and Biograph Company. VHS video transfer.

Mast, G. \& Kawin, B. eds. (2006). A Short History of the Movies. New York: Pearson Education, Inc.

Richardson, M. (2010).Otherness in Hollywood Cinema. Retrieved from http://trove.nla.gov.au/work/36333770?q\&sort=holdings+desc\&_=1378696242924\& versionId $=197531527$

Said, E. (1979). Orientalism. New York: Vintage Books.

Shohat, E. (1991). "Gender and Culture of Empire: Toward a feminist Ethnography of the Cinema." in Quarterly Review of Film and Video, Volume 13 (1-3), pp. 45-84.

Sotto, A. (1995). Respondent at the "Conference on Cinema and Society: Reflections on the Development of Cinema in the Philippines. De Ia Salle University. February 2.

Spivak, G. C. (1985). "The Rani of Sirmur" in Barker, Francis, ed. Europe and its Others. Colchester: University of Essex.

Tiongson, N. "Film and History" (1981). DLSU Dialogue, Volume XVI, Number 2, March. 